\title{
Proteomic analysis of broccoli (Brassica oleracea) under high temperature and waterlogging stresses
}

\author{
Hsin-Hung Lin ${ }^{1+}$, Kuan-Hung Lin ${ }^{2 \dagger}$, Su-Ching Chen ${ }^{2}$, Yu-Hsing Shen ${ }^{3}$ and Hsiao-Feng Lo ${ }^{1 *}$
}

\begin{abstract}
Background: The production of broccoli (Brassica oleracea) is largely reduced by waterlogging and high temperature stresses. Heat-tolerant and heat-susceptible broccoli cultivars TSS-AVRDC-2 and B-75, respectively, were used for physiological and proteomic analyses. The objective of this study was to identify TSS-AVRDC-2 and B-75 proteins differentially regulated at different time periods in response to waterlogging at $40{ }^{\circ} \mathrm{C}$ for three days.

Results: TSS-AVRDC-2 exhibited significantly higher chlorophyll content, lower stomatal conductance, and better $\mathrm{H}_{2} \mathrm{O}_{2}$ scavenging under stress in comparison to B-75. Two-dimensional liquid phase fractionation analyses revealed that Rubisco proteins in both varieties were regulated under stressing treatments, and that TSS-AVRDC-2 had higher levels of both Rubisco large and small subunit transcripts than B-75 when subjected to high temperature and/or waterlogging.

Conclusions: This report utilizes physiological and proteomic approaches to discover changes in the protein expression profiles of broccoli in response to heat and waterlogging stresses. Higher levels of Rubisco proteins in TSS-AVRDC-2 could lead to increased carbon fixation efficiency to provide sufficient energy to enable stress tolerance under waterlogging at $40^{\circ} \mathrm{C}$.
\end{abstract}

Keywords: Ribulose bisphosphate carboxylase; Broccoli; Heat and waterlogging stresses; Differentially expressed proteins

\section{Background}

Broccoli (Brassica oleracea var. italica) is a member of the Brassicaceae family. This cole crop is not only economically important but also provides nutrients that have anticancer characteristics (Aggarwal and Ichikawa 2005). Under optimal temperatures of 18 to $25{ }^{\circ} \mathrm{C}$, this plant grows normal flower buds and forms one large central head. However, when temperature exceeds $30{ }^{\circ} \mathrm{C}$, heads become loose and branchy, tend to develop leaf-like structures, and initial floret development is disrupted (Bjorkman and Pearson 1998). Taiwan is located in tropical and subtropical regions where daily temperatures exceed $30{ }^{\circ} \mathrm{C}$ during summer (June to September), thus reducing the quality and quantity of broccoli produced.

\footnotetext{
* Correspondence: hflo@ntu.edu.tw

${ }^{\dagger}$ Equal contributors

'Department of Horticulture and Landscape Architecture, National Taiwan University, Taipei, Taiwan

Full list of author information is available at the end of the article
}

Moreover, typhoons always bring heavy rains in summer, and flooding from typhoon rainfall is a major risk to fresh-market broccoli production when the soil is watersaturated.

Previous studies report that when plants are subjected to high temperature and waterlogging, the water and chlorophyll in leaves are decreased but the level of hydrogen peroxide in the cells is increased, resulting in reduced plant growth and development (Moller and Kristensen 2004; Kumutha et al. 2009; Pucciariello et al. 2012). Fortunately, plants have developed several mechanisms to protect themselves from stressful abiotic environments, some of which overlap. For example, pretreating Arabidopsis with $38{ }^{\circ} \mathrm{C}$ for 90 min results in a higher tolerance to waterlogging (Banti et al. 2010). Additionally, waterlogging can also stimulate the expression of heat shock factors and proteins as effectively as high temperature (Banti et al. 2010). These findings demonstrate that responses to different stress factors in 
plants are coordinated by complex and interconnected signaling pathways. Different sets of genes have been identified that activate against various abiotic stresses, including heat, flood, drought, cold, and intense light (Kreps et al. 2002; Seki et al. 2002; Rizhsky et al. 2004). However, little is known about how the simultaneous occurrence of multiple abiotic stresses, as opposed to individual stresses, damage crop production (Rizhsky et al. 2004; Mittler 2006; Atkinson and Urwin 2012). Therefore, uncovering the physiological mechanisms whereby plants can withstand combined waterlogging and high temperature stressing is greatly desired.

Proteomic analysis is a powerful approach for revealing differentially expressed proteins under given conditions. Liu et al. discovered a large number of differentially expressed proteins from broccoli florets treated with $\mathrm{N}^{6}$ benzylaminopurine, illuminating a complex network that provides comprehensive information on post-harvest yellowing response mechanisms (Liu et al., 2011; Liu et al., 2013). Using two-dimensional liquid phase fractionation (PF2D) and matrix-assisted laser desorption ionization time-of-flight mass spectrometry (MALDI-TOF MS), we identified 31 differentially expressed proteins from heat-tolerant and heat-susceptible broccoli cultivars TSS-AVRDC-2 and B-75, respectively, under high temperature and/or waterlogging stresses. We then further cloned the stress-responsive Rubisco genes and their transcript levels under stressing were determined. The possible mechanism whereby TSS-AVRDC-2 broccoli develops florets during summer is also discussed herein.

\section{Methods}

Plant materials, culturing, and heat- and flood-stress treatments

Seeds of broccoli (B. oleracea) varieties TSS-AVRDC-2 and B-75 were obtained as gifts from Mr. L.C. Chung (see Acknowledgments) at AVRDC (Vegetable Research and Development Center) - the World Vegetable Center, Tainan, Taiwan. B-75 is a heat-sensitive variety that requires optimum growing temperatures for satisfactory production. However, TSS-AVRDC-2 is a heat-tolerant variety suitable especially for warm-subtropical regions such as southern Taiwan where average day temperatures reach as high as $40{ }^{\circ} \mathrm{C}$ during summer. Seeds of TSS-AVRDC-2 and B-75 were immersed in distilleddeionized (dd) water in darkness for $24 \mathrm{~h}$ and germinated on wetted Whatman filter papers for three days to ensure uniform germination. Seedlings were then transplanted into 5-inch plastic pots containing a mixture of peat and moss $(4: 1, \mathrm{v}: \mathrm{v})$ and placed in a growth chamber under $300 \mu \mathrm{mol} \mathrm{m} \mathrm{m}^{-2} \mathrm{~s}^{-1}$ light with a $16 \mathrm{~h}$ photoperiod provided by fluorescent and incandescent light. The temperature was maintained at $22{ }^{\circ} \mathrm{C}$ in the light and $18{ }^{\circ} \mathrm{C}$ in the dark, with a relative humidity (RH) of $80 \%$.
Plants were watered with a half-strength Hoagland solution (Hoagland and Arnon 1950) three times a week to maintain optimal irrigation and growth for 40 days before imposing heat and waterlogging stresses.

Pots of TSS-AVRDC-2 and B-75 plants were divided into four groups and transferred to $20{ }^{\circ} \mathrm{C}$ without waterlogging $\left(\mathrm{C}\right.$, control), $20{ }^{\circ} \mathrm{C}$ with waterlogging $(\mathrm{F}), 40{ }^{\circ} \mathrm{C}$ without waterlogging $(\mathrm{H})$, and $40{ }^{\circ} \mathrm{C}$ with waterlogging (HF) for periods of $0,12,24,48$, and $72 \mathrm{~h}$ (for chlorophyll content and $\mathrm{H}_{2} \mathrm{O}_{2}$ content experiments) or 0,24 , $36,48,60,72,96,120$ and $144 \mathrm{~h}$ (for stomatal conductance experiment) in four growth chambers under the above-described conditions. In the waterlogging treatments, pots were randomly placed in $28 \times 14 \times 14 \mathrm{~cm}$ plastic buckets and subjected to flooding by filling the buckets with tap water to $5 \mathrm{~cm}$ above the soil surface. Pots were removed from the buckets at different times following flooding, and plants were removed and leaves from each plant were clipped, frozen in liquid nitrogen, and stored at $-80{ }^{\circ} \mathrm{C}$ in an ultrafreezer until use. Three replicates from each time interval for the four treatments were randomly placed in a growth chamber. The experiment was performed twice independently for a randomized design of growth environment, sampling day, and physiological analysis.

\section{Measurement of chlorophyll content (CC), stomatal conductance (SC), and $\mathrm{H}_{2} \mathrm{O}_{2}$ content (HC)}

Characteristic physiological responses of plants to different treatments were evaluated to determine if the defense mechanisms of the genotypes are related to their $\mathrm{CC}, \mathrm{SC}$, and $\mathrm{HC}$ values. Relative CC unit leaf area was determined according to a previous study (Davenport et al. 2005) using a SPAD (Soil Plant Analysis Development) analyzer (SPAD-502 Chlorophyll Meter, Konica Minolta, Tokyo, Japan). Stomatal conductance values were measured with a Porometer (Decagon Devices, Pullman, WA). The sensor was equilibrated by considering water vapor in the ambient atmosphere as $0 \%$ relative humidity and wetted filter paper at $100 \%$ relative humidity. After equilibration, each leaf was inserted into the head of the Porometer sensor and a measurement taken (Limm et al. 2009). HC measurement was previously described (Wei et al. 2012). Briefly, each leaf was homogenized in liquid nitrogen and ice-cold extraction buffer $(50 \mathrm{mM}$ sodium phosphate buffer, $\mathrm{pH}$ 6.8, and $1 \mathrm{mM}$ hydroxylamine) then added. The mixture was centrifuged at $12,000 \mathrm{~g}$ for $10 \mathrm{~min}$ at $4{ }^{\circ} \mathrm{C}$ and an equal amount of titanium reagent $\left(0.1 \% \mathrm{TiCl}_{2}\right.$ in $\left.20 \% \mathrm{H}_{2} \mathrm{SO}_{4}\right)$ added to the supernatant. The titanium reagent mixtures were centrifuged at $12,000 \mathrm{~g}$ for $10 \mathrm{~min}$ and supernatants measured at $410 \mathrm{~nm}$ absorbance. $\mathrm{H}_{2} \mathrm{O}_{2}$ content was computed from a standard curve prepared from $\mathrm{H}_{2} \mathrm{O}_{2}$ solutions of known concentrations. 
Data shown in Figs. 1, 2 and 3 represent the mean of at least two independent sets of experiments with similar results. Measurements of physiological parameters were analyzed by analysis of variance (ANOVA) with completely randomized design. For significant values, means were separated by the least significant difference (LSD) test at $p \leq 0.05$ using PC SAS 8.2 (SAS Institute, Cary, $\mathrm{NC}, \mathrm{USA})$.

\section{Protein isolation and quantification}

Two grams of frozen leaf samples were ground into powder in liquid nitrogen, extracted with $7 \mathrm{ml}$ extraction buffer $(5 \%[\mathrm{v} / \mathrm{v}] 2$-mercaptoethanol, $2 \%[\mathrm{w} / \mathrm{v}]$ polyvinylpolypyrrolidone, $0.5 \%[\mathrm{w} / \mathrm{v}]$ sodium dodecyl sulfate, $10 \%$ [v/v] glycerol, and $60 \mathrm{mM}$ Tris- $\mathrm{HCl}, \mathrm{pH} 6.8)$, and centrifuged for $30 \mathrm{~min}$ at $13,000 \mathrm{~g}$ at $4{ }^{\circ} \mathrm{C}$. Supernatants were transferred to a new tube and ice-cold acetone was added, and placed at $-20{ }^{\circ} \mathrm{C}$ for $1 \mathrm{~h}$. Precipitated proteins were collected after centrifuging at 5,000 $\mathrm{g}$ for $30 \mathrm{~min}$ at $4{ }^{\circ} \mathrm{C}$. Pellets were then washed with ice-cold acetone three times, vacuum-dried, and kept at $-80{ }^{\circ} \mathrm{C}$ until use. Protein concentration was determined using the Bradford method (Protein Assay, Bio-Rad Laboratories, Hercules, CA), and bovine serum albumin (BSA) was used as a protein standard.

\section{2-D liquid phase fractionation analysis and protein identification by MALDI-TOF MS and database search}

A first-dimension high performance chromatofocusing column (Beckman Coulter, CA, USA) was pre-equilibrated with starting buffer $(20 \mathrm{mM}$ Tris- $\mathrm{HCl}, \mathrm{pH} 8.5)$ until column $\mathrm{pH}$ reached 8.3. Samples were then injected into the column at a flow rate of $0.2 \mathrm{ml} / \mathrm{min}$ and column effluent was monitored at an absorbance of $280 \mathrm{~nm}$. The $\mathrm{pH}$ gradient was created by an elution buffer (polybuffer 74, $\mathrm{pH} 4.0$; GE Healthcare, NJ, USA) and fractions were collected every $0.3 \mathrm{pH}$ unit. In the second dimension, fraction separation was performed using a $4.6 \times 30 \mathrm{~mm}$ nonporous C18 HPRP column (Beckman Coulter) at $50{ }^{\circ} \mathrm{C}$ at a flow rate of $0.75 \mathrm{ml} / \mathrm{min}$. Solvent A (0.1\% w/v trifluroracetic acid) and solvent B $(0.08 \% \mathrm{w} / \mathrm{v}$ acetonitrile) were used to create a gradient. The gradient consisted of solvent $\mathrm{A}$ at $100 \%$ for $10 \mathrm{~min}$ and solvent $\mathrm{B}$ at 0 to $60 \%$ for $30 \mathrm{~min}$, and eluent was collected every $15 \mathrm{~s}$, and was monitored at an absorbance of $214 \mathrm{~nm}$. Protein peaks from those treated and untreated plants were compared using DeltaVue software (Beckman Coulter, Inc. Fullerton, CA, USA). DeltaVue allowed side-by-side viewing of the second-dimension runs for two samples, and was used to compare and quantify the number of differential expressed protein between them. Each band shown in this chromatogram represented a
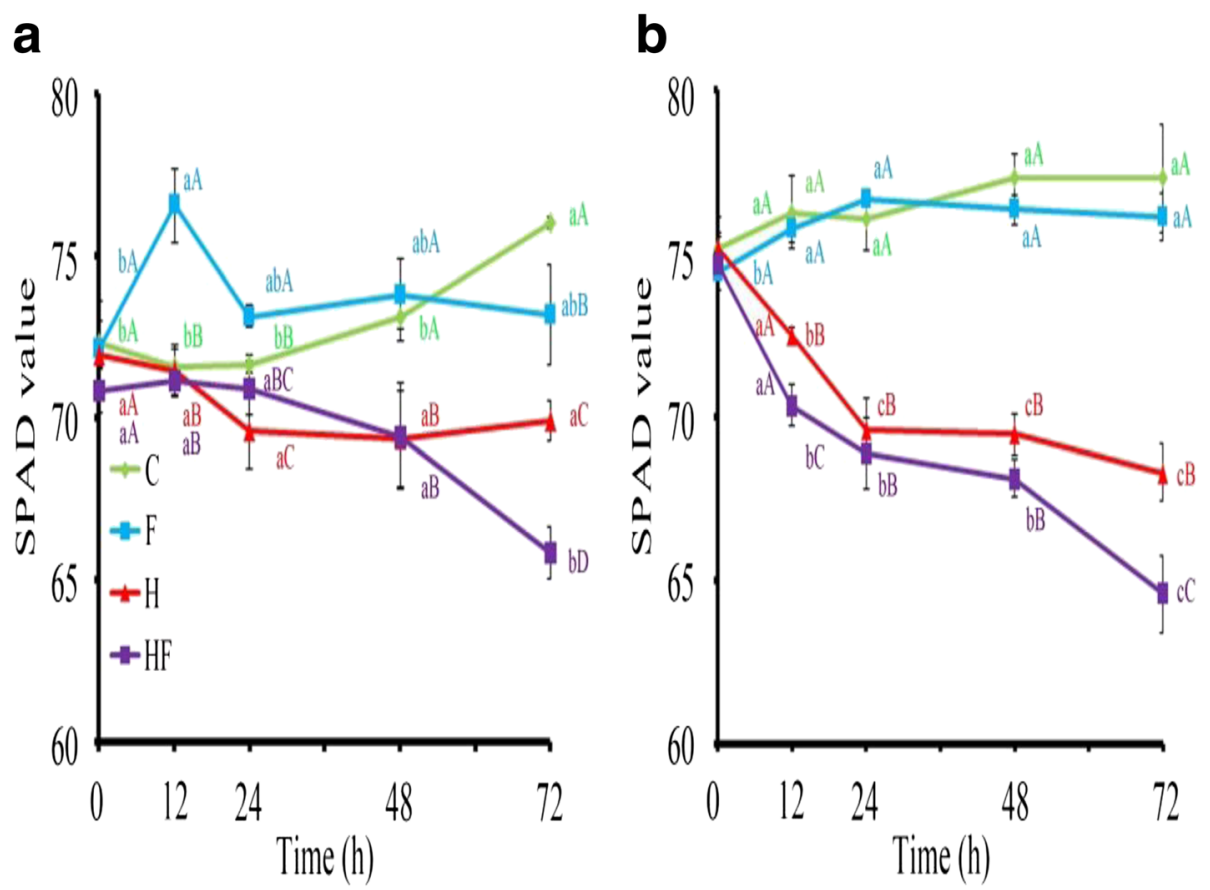

Fig. 1 Chlorophyll content in stressed plants. Leaf SPAD values in TSS-AVRDC-2 (a) and B-75 (b) plants under control (C), waterlogging (F), $40{ }^{\circ} \mathrm{C}$ $(\mathrm{H})$, and waterlogging at $40^{\circ} \mathrm{C}(\mathrm{HF})$ treatments for $0,12,24,48$, and $72 \mathrm{~h}$. Values represent the means of five independent plants. Values represent the means of five independent plants. Means with the same small letters are not significantly different among times within the same row, based on LSD at $p \leq 0.05$ under ANOVA. Means with the same capital letters are not significantly different between treatments within the same time point, based on LSD at $p \leq 0.05$ under ANOVA 

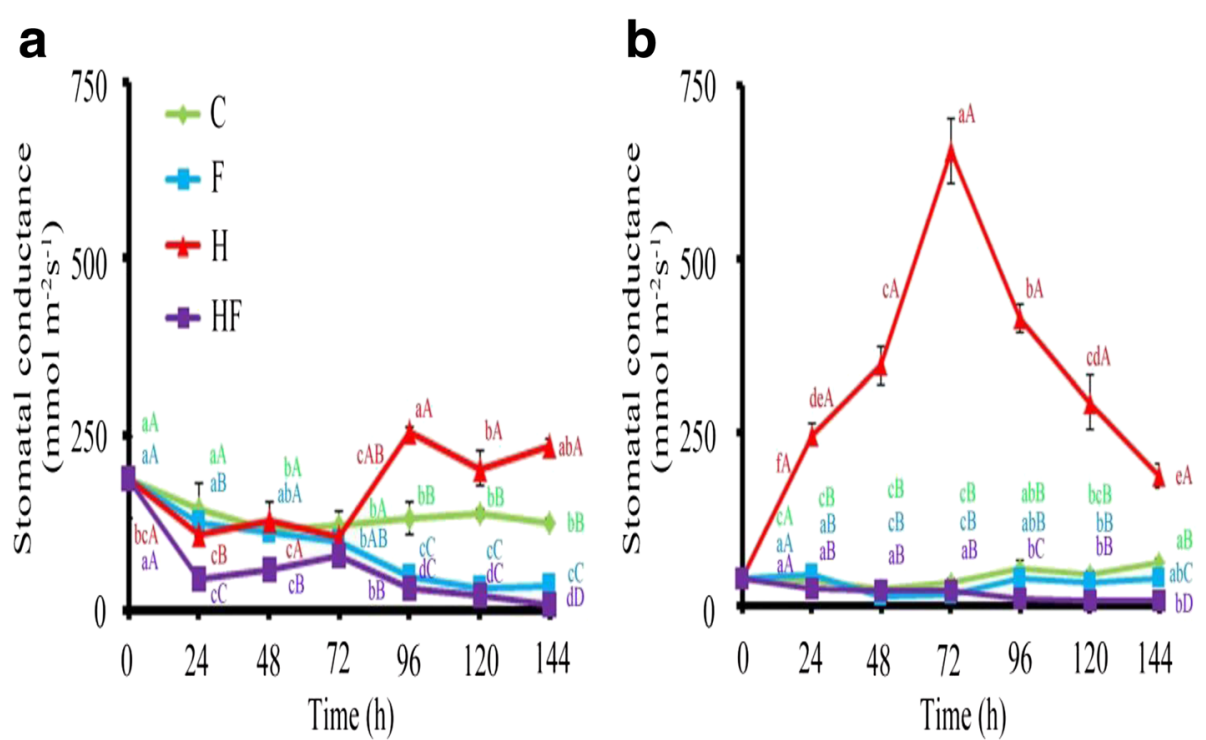

Fig. 2 Stomatal conductance in stressed plants. Stomatal conductance in TSS-AVRDC-2 (a) and B-75 (b) plants under control (C), waterlogging (F), $40{ }^{\circ} \mathrm{C}(\mathrm{H})$, and waterlogging at $40^{\circ} \mathrm{C}(\mathrm{HF})$ treatments for $0,24,72,48,96,120$, and $144 \mathrm{~h}$. Values represent the means of five independent plants. Values represent the means of five independent plants. Means with the same small letters are not significantly different among times within the same row, based on LSD at $p \leq 0.05$ under ANOVA. Means with the same capital letters are not significantly different between treatments within the same time point, based on LSD at $p \leq 0.05$ under ANOVA

singly separated protein and the relative intensity of the colors was directly proportional to the difference in protein concentration. The up-regulation and down-regulation of the proteins were identified (Additional file 1: Figures S1 and Additional file 2: Figure S2).
The eluents were dried under a vacuum and the pellet dissolved in a reducing solution $(50 \mathrm{mM}$ ammonium bicarbonate and $10 \mathrm{mM}$ dithiothreitol) for $60 \mathrm{~min}$ at $60{ }^{\circ} \mathrm{C}$. After reduction steps, protein solutions were digested at $37^{\circ} \mathrm{C}$ for $16 \mathrm{~h}$ with $5 \mathrm{ng} / \mu \mathrm{L}$ of trypsin. Tryptic digestion

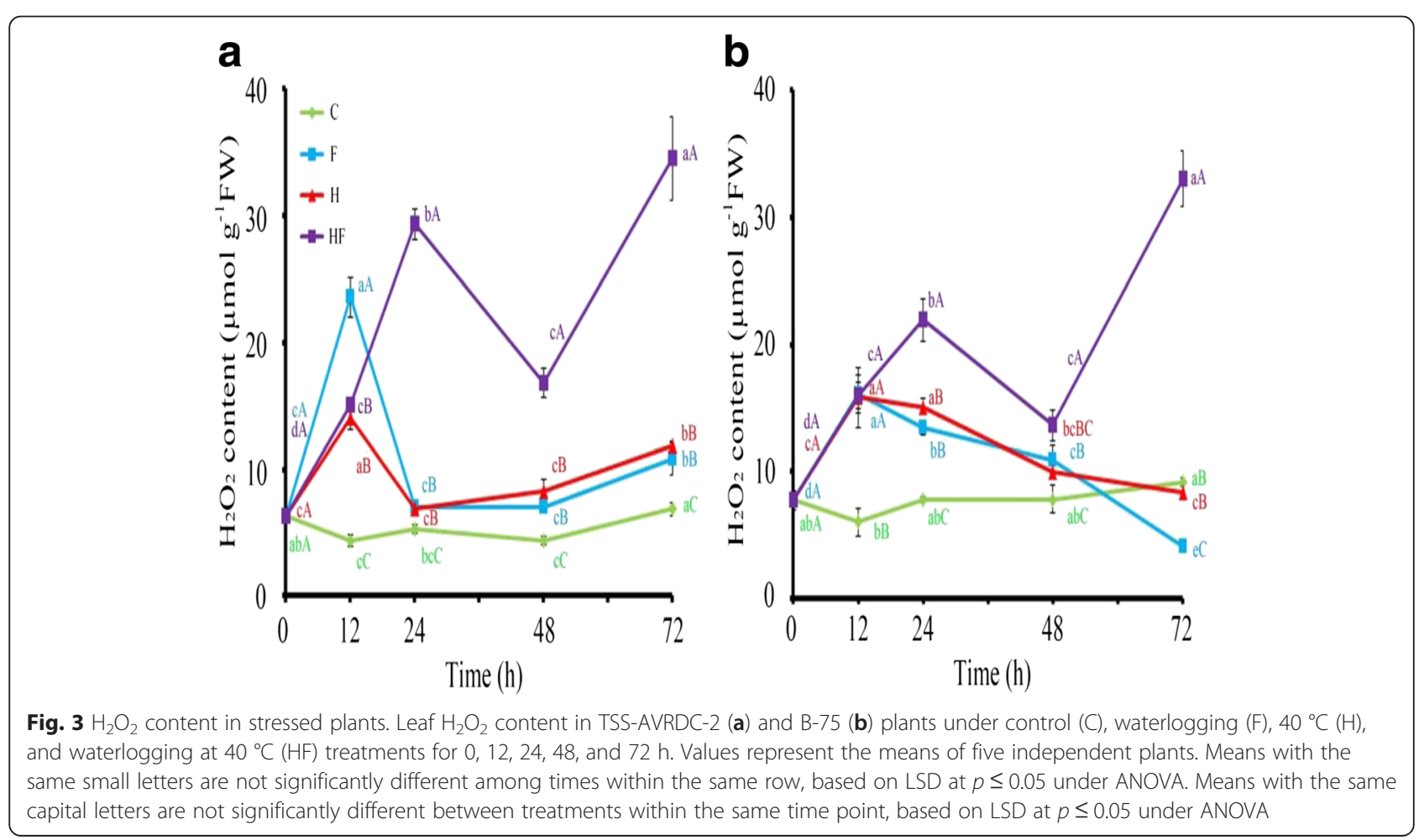


was stopped by adding $1 \%$ (v/v) formic acid. Digested proteins were further analyzed by MALDI-TOF MS. Mass spectra values were searched against NCBI and Swiss-Prot protein databases using the Mascot search program (http://www.matrixscience.com). The search parameters were set as follows: 1 missed cleavage, fixed modification, peptide charge \pm 1 , and variable modifications were carbamidomethyl of cysteine and oxidation of methionine. Trypsin was specified as the proteolytic enzyme. Peptide tolerance and MS mass tolerance were $50 \mathrm{ppm}$ and $0.25 \mathrm{Da}$, respectively. Peptide mass fingerprinting match confidence was based on the MOWSE score and confirmed by accurate overlapping of matched peptides with mass spectrum major peaks. Scores greater than $67 \quad(p<0.05)$ were considered positive. Peaks with multiple proteins detected by MS were not considered. Only significant hits, as defined by MASCOT probability analysis $(p<0.05)$, were accepted. To identify differentially expressed proteins, the protein peaks from waterlogging $(\mathrm{F}), 40{ }^{\circ} \mathrm{C}(\mathrm{H})$, and $40{ }^{\circ} \mathrm{C}$ with waterlogging (HF) at 12-h and 24-h time points were compared to those from the control sample $\left(20^{\circ} \mathrm{C}\right)$.

\section{Amplification and cloning of RubS and RubL from TSS- AVRDC-2 and B-75}

For amplification and cloning experiments, genomic $(\mathrm{g})$ DNA was isolated from mature TSS-AVRDC-2 and B-75 leaves based on the CTAB-based method from a previous study (Han et al. 2012). In brief, each leaf sample was ground into powder in liquid nitrogen, extracted with $65{ }^{\circ} \mathrm{C}$ preheated CTAB extraction buffer $(2 \%[\mathrm{v} / \mathrm{v}]$ CTAB, $2 \%[\mathrm{w} / \mathrm{v}]$ polyvinylpolypyrrolidone, $2 \%[\mathrm{w} / \mathrm{v}]$ PVP-40000, $1.4 \mathrm{M} \mathrm{NaCl}, 2$ \% 2-mercaptoethanol, $100 \mathrm{mM}$ Tris $\mathrm{HCl}, \mathrm{pH} 8.0$ and 20 mM EDTA, pH 8.0), incubated at $65{ }^{\circ} \mathrm{C}$ for $1 \mathrm{~h}$, and centrifuged for $20 \mathrm{~min}$ at $13,000 \mathrm{~g}$ at $4{ }^{\circ} \mathrm{C}$. An equal volume of chloroform was added to the supernatant. The supernatant was transferred and precipitated with isopropanol. Total RNA was isolated from leaves of TSS-AVRDC-2 and B-75 with Trizol reagent (Invitrogen, CA, USA) according to manufacturer instructions. In brief, each leaf sample was ground into powder in liquid nitrogen and extracted with Trizol reagent. Another 0.2 volume of chloroform was added and centrifuged for $15 \mathrm{~min}$ at $13,000 \mathrm{~g}$ at $4{ }^{\circ} \mathrm{C}$. A 0.5 volume of isopropanol was added to the supernatant to precipitate RNA at $4{ }^{\circ} \mathrm{C}$ for $2 \mathrm{~h}$ and centrifuged for $20 \mathrm{~min}$ at $13,000 \mathrm{~g}$ at $4{ }^{\circ} \mathrm{C}$. The pellet was washed with $75 \%$ ethanol twice and re-suspended in diethyl pyrocarbonate-treated deionized water. The quality of the total RNA was resolved by formaldehyde gel. Complementary (c) DNA was synthesized by using 1 ug of total RNA, Moloney Murine Leukemia Virus Reverse Transcriptase, and polyT primer as described previously (Chen et al. 2008). The gene specific primer pairs RubS-F (5-atggcttcctctatgctctcc-3) and RubS-R (5- gcac cggtgaagcttggtgg-3), and RubL-F (5-atgtcaccacaaacagag ac-3) and RubL-R (5-gatctccttccatacttcac-3), were designed according the sequences of AtRubS and AtRubL and used for gene cloning. The gDNA and cDNA of TSS-AVRDC-2 and B-75 were treated as templates to amplify RubS and RubL sequences. The PCR products were purified by Qiagen gel extraction kits (Qiagen, Valencia, CA). The PCR products were ligated with a CloneJET PCR Cloning Kit (Thermo Scientific, Rochester, USA) using T4 DNA ligase. The inserts from individual colonies were amplified by PCR using the JetF (5-cgactcac tatagggagagcgg-3) and JetR (5-aagaacatcgattttccatggcag-3) primers and then sequenced. DNA sequences were aligned and compared with reference sequences using ClustalW (http://www.ebi.ac.uk/Tools/msa/clustalw2).

\section{Northern blot analysis}

Total RNA samples were extracted from plant leaves under stressed treatments to determine the expression levels of RubL and RubS in leaves of TSS-AVRDC-2 and B-75. Total RNA samples were separated by formaldehyde gel and blotted to Hybond $\mathrm{N}+$ membranes (GE Healthcare, NJ, USA) using a trans-blot semidry transfer cell (Bio-Rad) for $1 \mathrm{~h}$ at $400 \mathrm{~mA}$, followed by UV crosslinking. The radiolabeled RubL and RubS probes were produced by PCR reactions using TSS-AVRDC-2 cDNA clones as templates in the presence of $\alpha{ }^{32} \mathrm{P}$-dATP with RubL-F and $-\mathrm{R}$ and RubS-F and RubS- $\mathrm{R}$ primers, respectively. PCR reactions were labeled with $\alpha-{ }^{32}$ P-ATP using High Fidelity Taq DNA Polymerase (Thermo Scientific). Blots used for the analysis were prehybridized with hybridized buffer (6X SSC, 5X Denhardt's Solution, and $0.5 \%$ sodium dodecyl sulfate) at $55{ }^{\circ} \mathrm{C}$ for $2 \mathrm{~h}$. After the radiolabeled probes were added, hybridization was performed under the same conditions for another $16 \mathrm{~h}$. Blots were washed twice in half-diluted saline-sodium citrate buffer and $0.1 \%$ sodium dodecyl sulfate for $10 \mathrm{~min}$, followed by washing once in $10 \%$ saline-sodium citrate and $0.1 \%$ sodium dodecyl sulfate for $15 \mathrm{~min}$. Radioactive blots were then displayed on a Phosphor Imager (Molecular Dynamics, CA, USA). Ribosomal (r) RNA was analyzed after ethidium bromide staining and treated as a load control. The ratios of RubL and RubS RNA to 28S rRNA in each reaction were calculated and the ratio of the control reaction was treated as a value of one for determining the relative ratios of other reactions. To quantify expression levels, the radioactive signals and amounts of 28S rRNA were measured using computing laser densitometer ImageJ software (http://imagej.nih.gov/ij/), with radioactive signals being normalized by the amount of $28 \mathrm{~S}$ rRNA. The expression level of treatment $\mathrm{C}$ was treated as 1 for normalizing the relative expression levels of H, F, and HF treatments. Each experiment was replicated three times. 


\section{Results and discussions}

Phenotypic and physiological characteristics of broccoli plants treated by stresses

Plants display complex phenotypic and physiological responses to heat and flood stresses. It is necessary to identify physiological characteristics that reflect their complex underlying genetic make-up. Physiological phenotypes of 40-day-old TSS-AVRDC-2 and B-75 plants under control $(\mathrm{C})$ and various stress treatments $(\mathrm{F}, \mathrm{H}$, and $\mathrm{HF}$ ) for $12,24,48$, and $72 \mathrm{~h}$ were observed. Leaf chlorophyll content (CC) is an indicator of photosynthetic efficiency when plant responding to stresses (Augustine et al. 2015). Significant changes in CC (measured as SPAD) were observed between and among genotypes under stress. Figure 1 shows that the SPAD values of both cultivars under $\mathrm{C}$ and $\mathrm{F}$ conditions were higher than those under $\mathrm{H}$ and $\mathrm{HF}$ conditions after $12 \mathrm{~h}$. A significant reduction in SPAD values were observed in both cultivars treated by HF over time, but the reduction rate in B75 was more rapid than in TSS-AVRDC-2, indicating that the $\mathrm{CC}$ of both cultivars were not influenced by waterlogging and that TSS-AVRDC-2 maintained higher $\mathrm{CC}$ values than B-75 under high temperature and waterlogging treatments, except for after $24 \mathrm{~h}$. The SC parameter was chosen as an indirect proxy of plant physiology under stress regarding the level of leaf water loss and $\mathrm{CO}_{2}$ uptake. SC values of B-75 plants under condition $\mathrm{H}$ from $24 \mathrm{~h}$ to $120 \mathrm{~h}$ were significantly higher than in TSS-AVRDC-2 plants (Fig. 2), indicating that transpiration in B-75 was increased due to stomata being open at high temperatures. Moreover, the SC values of both cultivars under treatment $\mathrm{H}$ after $72 \mathrm{~h}$ were higher than in other treatments. No significant differences in $\mathrm{SC}$ values were observed between $\mathrm{F}$ and $\mathrm{HF}$ in both cultivars after $72 \mathrm{~h}$. These results suggest that stomata were closed when plants were waterlogged and that stomata closure under waterlogging and high temperatures was faster than under either waterlogging or high temperature treatments alone. Excess accumulation of $\mathrm{H}_{2} \mathrm{O}_{2}$ can lead to oxidative stress in plants, which then triggers cell death. $\mathrm{HC}$ elevates under waterlogging and high temperatures stresses in plants (Simova-Stoilova et al. 2012; Xu et al. 2014). Therefore, HC was assessed over time under various treatments (Fig. 3). Compared to B-75 plants, TSS-AVRDC-2 plants had lower HC under $\mathrm{H}$ treatment from 24 to $48 \mathrm{~h}$. Furthermore, the endogenous $\mathrm{H}_{2} \mathrm{O}_{2}$ content was elevated when both cultivars were exposed to HF stresses. Thus, high temperature plus waterlogging caused an overproduction of $\mathrm{H}_{2} \mathrm{O}_{2}$ in both genotypes, their $\mathrm{H}_{2} \mathrm{O}_{2}$ scavenging systems being unable to eliminate the extra $\mathrm{H}_{2} \mathrm{O}_{2}$. A combination of waterlogging and high temperature induced larger amounts of $\mathrm{H}_{2} \mathrm{O}_{2}$ than individual stresses in both cultivars.
Figures 1, 2 and 3 show that two cultivars displayed different physiological responses to various stress treatments. TSS-AVRDC-2 maintained significantly higher chlorophyll levels than B-75 under high temperature treatments at $24 \mathrm{~h}$ (Fig. 1), indicating that TSS-AVRDC2 has a better photosynthetic efficiency than B-75, displaying its characteristically high temperature tolerance. Typically, CC is reduced in amount by stressful conditions (Xu et al. 2014). This is consistent with our observations that chlorophyll loss was more pronounced in heat-sensitive B75 plants in accordance with the more pronounced and increased visible symptoms of leaf injury. In addition, the SC values of B-75 were largely increased from $0 \mathrm{~h}$ to $72 \mathrm{~h}$ under high temperature, whereas TSS-AVRDC-2 exhibited low SC values in order to prevent water loss (Fig. 2). Although wilted leaves were observed in TSS-AVRDC-2 and B-75 under stress treatments for at least $24 \mathrm{~h}, \mathrm{SC}$ values in both genotypes under F and HF treatment over time were low (Fig. 2). These results suggest that waterlogging results in stomata closure, which prevents transpiration. $\mathrm{H}_{2} \mathrm{O}_{2}$ acts as a ubiquitous marker of signaling events for the induction of adaptive stress responses and oxidative stress (Mittler et al. 2011). This dual function should be tightly regulated by the balancing of $\mathrm{H}_{2} \mathrm{O}_{2}$ production and scavenging (Mittler et al. 2004). When plants were treated with $\mathrm{H}_{2} \mathrm{O}_{2}$, their tolerances to high temperature and waterlogging were increased (Uchida et al. 2002; Banti et al. 2010). Plants often suffer from a simultaneous combination of high temperature and waterlogging. In our study, TSS-AVRDC-2 had a better $\mathrm{H}_{2} \mathrm{O}_{2}$ control system than B-75, and low levels of $\mathrm{H}_{2} \mathrm{O}_{2}$ increased tolerance to high temperature stress in TSS-AVRDC-2 (Fig. 3). However, waterlogging plus high temperature damaged broccoli plants more seriously than either high temperature or waterlogging alone, through the overproduction of $\mathrm{H}_{2} \mathrm{O}_{2}$. At the physiological level, the many effects of flooding and heat stresses indicate the importance of protecting plants from oxidative damage caused by the overproduction of $\mathrm{H}_{2} \mathrm{O}_{2}$.

\section{Differentially expressed proteins in plant leaves among stress treatments}

Changes in protein accumulation under stress likely are directly related to the physiological phenotypic response of plants to stress. To investigate the effects of single and combined stress treatments on the differential expression of proteins, leaf total protein was extracted from stressed 40-day-old TSS-AVRDC-2 and B-75 plants at $12 \mathrm{~h}$ and $24 \mathrm{~h}$. Fifteen and 16 protein peaks were identified from TSS-AVRDC-2 (Table 1; Additional file 1: Figure S1) and B-75 (Table 2; Additional file 2: Figure S2), respectively. These identified proteins emerged as key participants in stress tolerance. Among 31 identified proteins, 
Table 1 Identification of differentially expressed stress-related proteins in TSS-AVRDC-2 by MALDI-TOF-MS

\begin{tabular}{|c|c|c|c|c|c|c|c|}
\hline Treatment & $\begin{array}{l}\text { Stress Time } \\
(\mathrm{h})\end{array}$ & Peak & Homologous protein & Species & $\mathrm{Pl}$ & $\mathrm{S}^{\mathrm{a}}$ & $\begin{array}{l}\text { Accession } \\
\text { number }\end{array}$ \\
\hline \multirow[t]{6}{*}{ F } & 12 & 1 & Putative F-box protein At5g41500 & Arabidopsis thaliana & 8.9 & 74 & FB277_ARATH \\
\hline & \multirow[t]{5}{*}{24} & 2 & DNA-directed RNA polymerase subunit beta & $\begin{array}{l}\text { Geobacillus } \\
\text { thermodenitrificans }\end{array}$ & 8.9 & 86 & RPOC_GEOTN \\
\hline & & 3 & Conserved oligomeric Golgi complex subunit & Magnaporthe grisea & 4.9 & 66 & COG6_MAGO7 \\
\hline & & 4 & ATP synthase subunit beta & Brimeura amethystina & 5.2 & 76 & ATPB_BRIAM \\
\hline & & 5 & Rubisco large chain & Brassica oleracea & 5.8 & 96 & RBL_BRAOL \\
\hline & & 6 & Mitochondrial 2-oxoglutarate/malate carrier protein & Rattus norvegicus & 9.8 & 76 & M2OM_RAT \\
\hline \multirow[t]{4}{*}{$\mathrm{H}$} & \multirow[t]{4}{*}{24} & 7 & ATP synthase subunit beta & Nephroselmis olivacea & 5.2 & 90 & ATPB-NEPOL \\
\hline & & 8 & Phosphopantetheine adenylyltransferase & Silicibacter sp. & 5.4 & 76 & EEW57108 \\
\hline & & 9 & Ribosome-binding factor $\mathrm{A}$ & Salmonella choleraesuis & 5.9 & 62 & RBFA_SALCH \\
\hline & & 10 & $\begin{array}{l}\text { Pentatricopeptide repeat-containing protein } \\
\text { At2g01740 }\end{array}$ & Arabidopsis thaliana & 6.0 & 65 & PP141_ARATH \\
\hline \multirow[t]{5}{*}{$\mathrm{HF}$} & \multirow[t]{2}{*}{12} & 11 & Putative F-box protein At5g41500 & Arabidopsis thaliana & 8.9 & 74 & FB277_ARATH \\
\hline & & 12 & Eukaryotic translation initiation factor 3 & Saccharomyces cerevisiae & 5.4 & 54 & EIF3I YEAST \\
\hline & \multirow[t]{3}{*}{24} & 13 & Rubisco small chain & Brassica napus & 8.2 & 88 & PO5346 \\
\hline & & 14 & Ribosome-binding factor $\mathrm{A}$ & Salmonella choleraesuis & 5.9 & 54 & RBFA_SALCH \\
\hline & & 15 & $\begin{array}{l}\text { Pentatricopeptide repeat containing protein } \\
\text { At2g01740 }\end{array}$ & Arabidopsis thaliana & 6.0 & 65 & PP141_ARATH \\
\hline
\end{tabular}

a: Probability-based molecular weight search (Mowse) score

$\mathrm{F}$, waterlogging; $\mathrm{H}, 40^{\circ} \mathrm{C} ; \mathrm{HF}$, waterlogging at $40^{\circ} \mathrm{C}$

the expressed levels of RubL and RubS in TSS-AVRDC-2 HF treatment for $24 \mathrm{~h}$ compared to controls (Table 3). and B-75 plants under stress showed distinct differences. Furthermore, two RubS proteins (peaks 24, 27) in B-75 In TSS-AVRDC-2 plants, RubL protein (peak 5) was up- were up-regulated by either for $12 \mathrm{~h}$ HF treatment or regulated under $\mathrm{F}$ treatment for $24 \mathrm{~h}$ compared to con- $24 \mathrm{~h} \mathrm{H}$ treatment, while RubL proteins (peak 16) were trols, and RubS protein (peak 13) was up-regulated under down-regulated by F, H and HF treatments for $12 \mathrm{~h}$

Table 2 Identification of differentially expressed stress-related proteins in B-75 by MALDI-TOF-MS

\begin{tabular}{|c|c|c|c|c|c|c|c|}
\hline Treatment & Stressed Time (h) & Peak & Homologous protein & Species & $\mathrm{Pl}$ & $S^{a}$ & Accession number \\
\hline $\mathrm{C}$ & 12 & 16 & Rubisco large chain & Brassica oleracea & 5.8 & 78 & RBL_BRAOL \\
\hline \multirow[t]{3}{*}{$\mathrm{F}$} & 12 & 17 & ATP synthase subunit beta & Acutodesmus obliquus & 5.2 & 66 & ATPB ACUOB \\
\hline & 24 & 18 & Inorganic pyrophosphatase & Corynebacterium efficiens & 4.5 & 70 & Q8FMF8 \\
\hline & & 19 & tRNA pseudouridine synthase B & Mycobacterium avium & 8.2 & 74 & $\mathrm{~A} 0 \mathrm{Q} \mid \mathrm{X} 1$ \\
\hline \multirow[t]{7}{*}{$\mathrm{H}$} & 12 & 20 & DNA-directed RNA polymerase subunit beta & Staphylococcus haemolyticus & 6.1 & 61 & RPOC_STAHJ \\
\hline & & 21 & Probable O-sialoglycoprotein endopeptidase & $\begin{array}{l}\text { Leptospira borgpetersenii Serovar } \\
\text { hardjo-bovis }\end{array}$ & 5.7 & 75 & ABJ76496 \\
\hline & & 22 & Cysteinyl-tRNA synthetase & Lactococcus lactis subsp. & 4.8 & 72 & SYC_LACLS \\
\hline & 24 & 23 & Formin like protein 19 & Arabidopsis thaliana & 9.1 & 56 & Q9FF14 \\
\hline & & 24 & Rubisco small chain & Brassica napus & 8.2 & 98 & PO5346 \\
\hline & & 25 & Putative uncharacterized protein yibJ & Escherichia coli & 5 & 60 & P32109 \\
\hline & & 26 & Thiamine biosynthesis protein thiC & Shewanella halifaxensis & 5.1 & 78 & B0TRP7 \\
\hline \multirow[t]{5}{*}{ HF } & 12 & 27 & Rubisco small chain & Brassica napus & 8.2 & 97 & RBS1_BRANA \\
\hline & & 28 & tRNA 2-thiocytidine biosynthesis protein ttcA & Sorangium cellulosum & 7.0 & 76 & TTCA_SORC5 \\
\hline & & 29 & Myosin-1 & Canis familiaris & 5.6 & 83 & MYH1_CANFA \\
\hline & 24 & 30 & Putative uncharacterized protein yibJ & Escherichia coli & 5 & 68 & P32109 \\
\hline & & 31 & Haptoglobin & Mesocricetus auratus & 5.7 & 81 & O35086 \\
\hline
\end{tabular}


Table 3 Highly differentially expressed protein pattern in stressed TSS-AVRDC-2

\begin{tabular}{|c|c|c|c|c|}
\hline $\begin{array}{l}\text { Stressed } \\
\text { time (h) } \\
\end{array}$ & Homologue protein & Flooding & $40^{\circ} \mathrm{C}$ & $\begin{array}{l}\text { Flooding } \\
\text { at } 40^{\circ} \mathrm{C}\end{array}$ \\
\hline \multirow[t]{2}{*}{12} & $\begin{array}{l}\text { Putative F-box protein } \\
\text { At5g41500 }\end{array}$ & + & - & + \\
\hline & $\begin{array}{l}\text { Eukaryotic translation initiation } \\
\text { factor } 3\end{array}$ & - & - & + \\
\hline \multirow[t]{9}{*}{24} & $\begin{array}{l}\text { DNA-directed RNA polymerase } \\
\text { subunit beta }\end{array}$ & + & - & - \\
\hline & Rubisco large chain & + & - & - \\
\hline & Rubisco small chain & - & - & + \\
\hline & $\begin{array}{l}\text { Conserved oligomeric Golgi } \\
\text { complex subunit }\end{array}$ & + & - & - \\
\hline & ATP synthase subunit beta & + & + & - \\
\hline & $\begin{array}{l}\text { Mitochondrial 2-oxoglutarate/ } \\
\text { malate carrier protein }\end{array}$ & + & - & - \\
\hline & $\begin{array}{l}\text { Phosphopantetheine } \\
\text { adenylyltransferase }\end{array}$ & - & + & - \\
\hline & Ribosome-binding factor A & - & + & + \\
\hline & $\begin{array}{l}\text { Pentatricopeptide repeat- } \\
\text { containing protein }\end{array}$ & - & + & + \\
\hline
\end{tabular}

+ , up-regulated protein; -, down-regulated protein

(Table 4). Rubisco proteins are responsible for carbon fixation in plants and were regulated by stressing (Bose et al. 1999). To confirm these results, the RNA expression levels of RubL and RubS in TSS-AVRDC-2 and B-75 under stressing were analyzed.

In the present study, we analyzed physiological and proteomics data in different genotypes of broccoli under high-temperature and waterlogging stresses for different time periods. For survival, plants must respond to flood and/or heat stresses differently from the way they regulate protein expression during biochemical and physiological adaptations. Photosynthesis is one of the systems that is most sensitive to high-temperature stress (Salvucci 2008; Wang et al. 2015). Photosynthesis systems were protected from the damages caused by waterlogging and/or heat in TSS-AVRDC-2, which led to physiological phenomena such as high CC and low SC and $\mathrm{HC}$ in leaves. Chlorophyll functioning is not decreased in stressed thermo-tolerant plants ( $\mathrm{Li}$ et al. 2003; Xu et al. 2014). A temperature of $40{ }^{\circ} \mathrm{C}$ reduces photosynthesis, which seems to change the enzymatic response of a $\mathrm{CO}_{2}$-fixing enzyme, Rubisco (Markus et al. 1981). Thus, RubL and RubS were selected to do the further tests.

RubL and RubS transcripts were regulated when stressed In our study, Rubisco subunits (small and large chain) related to photosynthesis were differentially expressed and regulated by combination treatments and between genotypes (Tables 1 and 2). RubL and RubS sequences were cloned from gDNA and cDNA of TSS-AVRDC-2
Table 4 Highly differentially expressed protein pattern in stressed B-75

\begin{tabular}{|c|c|c|c|c|}
\hline $\begin{array}{l}\text { Stressed } \\
\text { time }(h)\end{array}$ & Homologue protein & Flooding & $40^{\circ} \mathrm{C}$ & $\begin{array}{l}\text { Flooding } \\
\text { at } 40^{\circ} \mathrm{C}\end{array}$ \\
\hline \multirow[t]{8}{*}{12} & Rubisco large chain & - & - & - \\
\hline & Rubisco small chain & - & - & + \\
\hline & ATP synthase subunit beta & + & - & - \\
\hline & $\begin{array}{l}\text { DNA-directed RNA polymerase } \\
\text { subunit beta }\end{array}$ & - & + & - \\
\hline & $\begin{array}{l}\text { Probable O-sialoglycoprotein } \\
\text { endopeptidase }\end{array}$ & - & + & - \\
\hline & Cysteinyl-tRNA synthetase & - & + & - \\
\hline & $\begin{array}{l}\text { tRNA 2-thiocytidine biosynthesis } \\
\text { protein ttcA }\end{array}$ & - & - & + \\
\hline & Myosin-1 & - & - & + \\
\hline \multirow[t]{7}{*}{24} & Rubisco small chain & - & + & - \\
\hline & Inorganic pyrophosphatase & + & - & - \\
\hline & tRNA pseudouridine synthase $B$ & + & - & - \\
\hline & Formin like protein 19 & - & + & - \\
\hline & $\begin{array}{l}\text { Putative uncharacterized protein } \\
\text { yibJ }\end{array}$ & - & + & + \\
\hline & $\begin{array}{l}\text { Thiamine biosynthesis protein } \\
\text { thic }\end{array}$ & - & + & - \\
\hline & Haptoglobin & - & - & + \\
\hline
\end{tabular}

+ , up-regulated protein; -, down-regulated protein

and B-75 using RubL-F and $-\mathrm{R}$ and RubS-F and $-\mathrm{R}$ in pairs. Cloned sequences were aligned and compared with Arabidopsis RubL and RubS genes. The sequences of RubL in gDNA were $97.4 \%$ matched with reference sequences from Arabidopsis (Additional file 3: Figure S3), yet the RubS gene shows two introns in the gDNA sequences (Additional file 4: Figure S4). The cDNA identity of RubL and RubS between TSS-AVRDC-2 and B-75 was higher than $99 \%$. The transcript levels of RubL and RubS in TSS-AVRDC- 2 and B-75 were analyzed by Northern blot. RubL and RubS transcripts in both genotypes under control treatment were observed (Fig. 4). Compared to the transcript level of RubL in TSSAVRDC-2 controls at $72 \mathrm{~h}$, RubL transcripts were increased by $18 \%$ but decreased by $39 \%$ and $25 \%$ under F, H, and HF treatments, respectively (Fig. 4a). However, in B-75 plants, RubS transcripts decreased $75 \%$, $81 \%$, and $86 \%$ at F, $\mathrm{H}$ and $\mathrm{HF}$, respectively, compared to controls. RubS transcripts of TSS-AVRDC-2 decreased $51 \%$ at condition $\mathrm{F}$ at $72 \mathrm{~h}$, but increased by $10 \%$ and $62 \%$ under $\mathrm{H}$ and $\mathrm{HF}$ conditions, respectively, compared to controls (Fig. 4b). The transcript level of RubL in B-75 decreased $55 \%, 14 \%$, and $5 \%$ by F, $\mathrm{H}$, and HF treatments at $72 \mathrm{~h}$, respectively, compared to controls. These results suggest that the transcript abundance of RubL in TSS-AVRDC-2 was higher than that of B-75 under all stress treatments. 

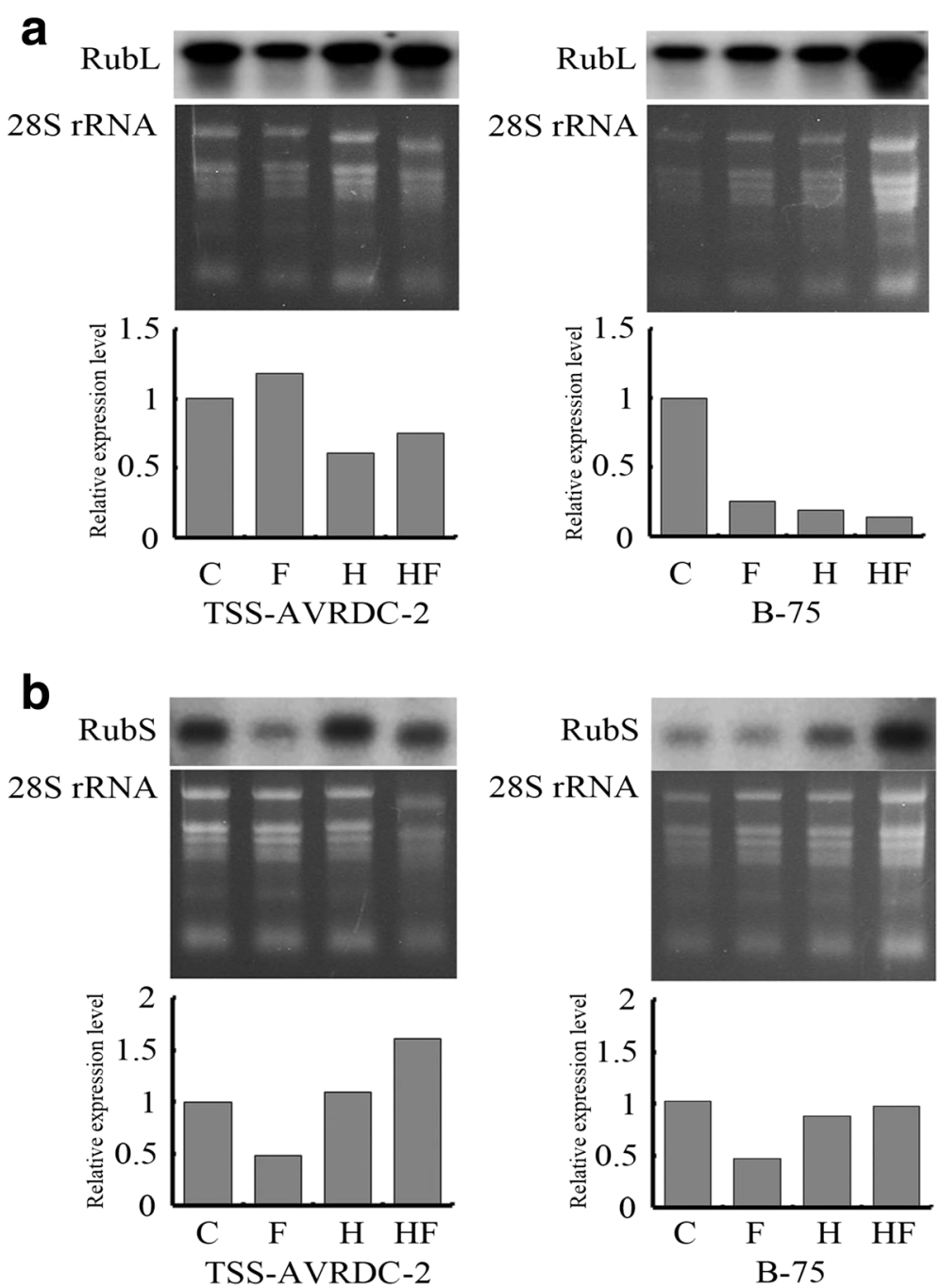

Fig. 4 Expression levels of Rubisco genes in stressed plants. Expression analysis of leaf Rubisco large (RubL, a) and small (RubS, b) RNA in TSS-AVRDC-2 and B-75 plants under control $(\mathrm{C})$, waterlogging $(\mathrm{F}), 40^{\circ} \mathrm{C}(\mathrm{H})$, and waterlogging at $40^{\circ} \mathrm{C}(\mathrm{HF})$ treatments for $72 \mathrm{~h}$. Total RNA was analyzed by RNA gel blotting with cDNA sequences of RubL and RubS subunits as specific gene probes. Ethidium bromide staining of 285 rRNA gel was shown as a loading control. The ratios of RubL and RubS RNA to $28 \mathrm{~S}$ rRNA in each reaction were calculated, and the ratio of the control reaction was treated as a value of one for determining the relative ratios of the other reactions

To increase energy metabolism, the expressions of proteins related to redox homeostasis and response to stimuli were up-regulated, thereby maintaining physiological balance during stress. An up-regulation in Rubisco levels may also indicate an increase in the photorespiration rate. Rubisco's large and small subunits were both identified as accumulated proteins, and subsequently RubL and RubS genes were cloned from TSS-AVRDC-2 and B-75. The coding sequences of RubL and RubS between TSSAVRDC-2 and B-75 were highly similar (Additional file 3: Figures S3 and Additional file 4: Figure S4), but their gene expression levels were different under stress treatments (Fig. 4). Compared to controls, the relative expression level of the RubL gene in TSS-AVRDC-2 plants under F stressing was 1.18, whereas the RubL transcript of the
B-75 plant was 0.25 (Fig. 4a). However, the relative expression levels of the RubS gene did not change too much in either TSS-AVRDC-2 (0.49) or B-75 (0.45) under F stressing (Fig. 4b). A similar trend applied to the high temperature condition. The relative expression levels of the RubS gene did not change too much in either TSS-AVRDC-2 (1.1) or B-75 (0.86) under $\mathrm{H}$ stressing (Fig. 4b). However, the relative expression level of the RubL gene in B-75 under $\mathrm{H}$ stressing was 0.19 , whereas the RubL transcript of TSSAVRDC-2 only dropped to 0.61 compared to controls (Fig. 4a). These results indicate that TSS-AVRDC-2 is tolerant to high temperature in summer via the transcriptional control of RubL, and that the maintenance of RubL transcripts may allow for a better photosynthetic efficiency in its tolerance to high temperature. Rubisco is the main 
enzyme responsible for the carboxylation reaction in plants. High temperatures decrease the stability and also depress the carboxylation reaction rate of Rubisco. Miller et al. (2013) demonstrated that the thermo-tolerant Synechococcus lineage containing higher Rubisco stability than other lineages. The Rubisco large subunit content, Rubisco activity, and $\mathrm{CO}_{2}$ assimilation capacity were protected from high temperature stress damage by chloroplast-targeted DnaJ (CDJ) in tomato (Wang et al. 2015). The CDJ overexpressed plants exhibited higher chlorophyll contents and fresh weights than the CJD knock-down plants. Meanwhile, heat-tolerant rice cultivar, N 22, had higher thermostability of the Rubisco protein than heat-sensitive cultivar, IR 8, under high temperature (Bose et al. 1999). These results indicate that heat-tolerant cultivar has a protective mechanism against thermal degradation of Rubisco. The maintenance of higher Rubisco subunit protein may help plants survival from the heat damages.

In this study, distinct protein profiles of TSS-AVRDC-2 and B-75 were generated and used for identifying differentially expressed protein profiles. Some of the proteins identified have been well characterized in terms of their response to stresses, while others have not been well studied with respect to their roles in the stress responses of plants. A ribosomal-binding factor A family $\operatorname{HrpA}$ was found in heat treated Mycobacterium bovis Bacillus Calmette-Gue'rin (Ohara et al. 1997; Tabira et al. 2000). Also, arabidopsis ribosome-binding factor A homolog $R B F 1$ is also essential for plastid protein biosynthesis (Fristedt et al. 2014). The increasing of ribosomal-binding factor may help in the translation of proteins, and further help plants tolerate heat stress. Our results show that the abundance of ribosome-binding factor A (peaks 9 and 14) in TSS-AVRDC-2 plants was also up-regulated after $24 \mathrm{~h}$ of $\mathrm{H}$ and $\mathrm{HF}$ treatment as compared to controls. Protein synthesis pathways were up-regulated in TSS-AVRDC-2 and helped TSS-AVRDC-2 tolerate high temperatures. Taken together, the genetic difference was supported by the high number of proteins differentially regulated between genotypes. Our data suggest that the early response of broccoli to flooding and high temperature might be an important stress adaptation for survival following not only hypoxia and heat, but also direct damage to cells by flooding and high temperature. All of the identified proteins likely work cooperatively to reestablish cellular homeostasis under stress. These findings are important for farming in high temperature areas and wetlands or other areas subject to short and intense rainfall events.

\section{Conclusions}

Environmental stresses represent the most limiting conditions for horticultural productivity and plant exploitation worldwide. The long term goal of our work is to help breed a competitively higher flood- and heat-tolerant broccoli to be grown in lowlands during summer. The identification of the unique stress-responsive proteins from TSS-AVRDC-2 under stressing, such as RubL, RubS, and ribosome- binding factor A, will allow further dissection of the genetic basis of this transgressive performance in its offspring. Our results not only provide information for selecting lines having better tolerance to waterlogging and heat stresses, but also provide a basis for understanding broccoli metabolic pathways and their cross-talk under stress.

\section{Additional files}

\begin{abstract}
Additional file 1: Figure S1. Representatives of second-column
separation in TSS-AVRDC-2 fractions. Leaf proteins from TSS-AVRDC-2 plants treated with $22^{\circ} \mathrm{C}$ (C; red lines), flooding at $22^{\circ} \mathrm{C}(\mathrm{F}), 40^{\circ} \mathrm{C}(\mathrm{H})$, and waterlogging at $40{ }^{\circ} \mathrm{C}(\mathrm{FH})$ for 12 and $24 \mathrm{~h}$ were separated with a two-dimensional protein fractionation (PF2D) system. The $Y$-axis represents the optical densitometry pattern (OD at $214 \mathrm{~nm}$ ). The $X$-axis represents retention time in minutes according to the concentration of acetonitrile in the mobile phase. Red lines indicate the absorbance after treatment $\mathrm{C}$. Green lines indicate the absorbance from treatment $F$ (a to d), treatment $\mathrm{H}$ (e to g), and treatment HF ( $\mathrm{h}$ to l), and the detected peaks were designated by numbers.
\end{abstract}

Additional file 2: Figure S2. Representatives of the second column separation of B-75 fractions. Leaf proteins from $\mathrm{B}-75$ plants treated with $22{ }^{\circ} \mathrm{C}\left(\mathrm{C}\right.$; red lines), flooding at $22{ }^{\circ} \mathrm{C}(\mathrm{F}), 38^{\circ} \mathrm{C}(\mathrm{H})$, and waterlogging at $40^{\circ} \mathrm{C}(\mathrm{FH})$ for 12 and $24 \mathrm{~h}$ were separated with PF2D. The $\mathrm{Y}$-axis represents optical densitometry pattern (OD at $214 \mathrm{~nm}$ ). The $\mathrm{X}$-axis represents retention time in minutes according to the concentration of acetonitrile in the mobile phase. Red lines indicate the absorbance from treatment C. Green lines indicate the absorbance from treatment $F$ ( $b$ and $d$ ), treatment $\mathrm{H}$ ( $a$ and $\mathrm{e}$ to j), and treatment HF ( $\mathrm{k}$ to o ), and the detected peaks were designated by numbers.

Additional file 3: Figure S3. RubL DNA sequence comparison analyses by ClustalW. CDNA sequences of RubL from TSS-AVRDC-2 and B-75 were compared with RubL in Arabidopsis, including AtRubL (ATCG00490). 'Star' indicates identical residues in all sequences. The line above the ATG letters indicates the translation start site.

Additional file 4: Figure S4. RubS DNA sequence comparison analyses by ClustalW. cDNA sequences of RubS from TSS-AVRDC-2 and B-75 were compared with RubS in Arabidopsis, including AtRubS (AT5G38420). 'Star' indicates identical residues in all sequences. The line above ATG letters indicates the translation start site.

\section{Abbreviations}

CC: Chlorophyll content; $\mathrm{H}_{2} \mathrm{O}_{2}$ : Hydrogen peroxide; MALDI-TOF-MS: Matrixassisted laser desorption ionization time-of-flight mass spectrometry; PF2D: Two-dimensional protein fractionation; RubL: Ribulose bisphosphate carboxylase large chain; RubS: Ribulose bisphosphate carboxylase small chain; SC: Stomatal conductance.

\section{Competing interests}

The authors declare that they have no competing interests.

\section{Authors' contributions}

$\mathrm{H}-\mathrm{H} \mathrm{L}$ and $\mathrm{K}-\mathrm{H} \mathrm{L}$ carried out conception of the research, and wrote the manuscript. $\mathrm{H}-\mathrm{H}$ L, S-J C, and Y-H S performed the experiment. H-F L supervised the entire study. All authors have read and approved the final manuscript.

\section{Acknowledgments}

We thank Mr. Lein-Chong Chung (now retired) from the Cruciferae Breeding Unit, AVRDC-The World Vegetable Center, Tainan, Taiwan, for the generous gift of broccoli seeds. This research was supported by grants from the Council of Agriculture (96-98 AS-6421.3.2.FD-Z2), and the National Science Council (NSC 97-2313-B-002-047-MY3), Taiwan, ROC. 


\section{Author details}

${ }^{1}$ Department of Horticulture and Landscape Architecture, National Taiwan University, Taipei, Taiwan. ${ }^{2}$ Department of Horticulture and Biotechnology, Chinese Culture University, Taipei, Taiwan. ${ }^{3}$ Institute of plant and microbial biology, Academia Sinica, Taipei, Taiwan.

Received: 30 November 2014 Accepted: 29 June 2015

Published online: 15 July 2015

\section{References}

Aggarwal BB, Ichikawa H (2005) Molecular targets and anticancer potential of indole-3-carbinol and its derivatives. Cell Cycle 4:1201-1215

Atkinson NJ, Urwin PE (2012) The interaction of plant biotic and abiotic stresses: from genes to the field. J Exp Bot 63:3523-3543

Augustine SM, Narayan JA, Syamaladevi DP, Appunu C, Chakravarthi M, Ravichandran V, Subramonian N (2015) Erianthus arundinaceus HSP70 (EaHSP70) overexpression increases drought and salinity tolerance in sugarcane (Saccharum spp. hybrid). Plant Sci 232:23-34

Banti V, Mafessoni F, Loreti E, Alpi A, Perata P (2010) The heat-inducible transcription factor HsfA2 enhances anoxia tolerance in Arabidopsis. Plant Physiol 152:1471-1483

Bjorkman T, Pearson KJ (1998) High temperature arrest of inflorescence development in broccoli (Brassica oleracea var. italica L.). J Exp Bot 49:101-106

Bose A, Tiwari BS, Manas KC, Gupta S, Ghosh B (1999) Thermal stress induces differential degradation of Rubisco in heat-sensitive and heat-tolerant rice. Physiol Plantarum 105:89-94

Chen YC, Lin HH, Jeng ST (2008) Calcium influxes and mitogen-activated protein kinase kinase activation mediate ethylene inducing ipomoelin gene expression in sweet potato. Plant Cell Environ 31:62-72

Davenport JR, Perry EM, Lang NS, Stevens RG (2005) Leaf spectral reflectance for nondestructive measurement of plant nutrient status. Horttechnology 15:31-35

Fristedt R, Scharff LB, Clarke CA, Wang Q, Lin C, Merchant SS, Bock R (2014) RBF1, a plant homolog of the bacterial ribosome-binding factor RbfA, acts in processing of the chloroplast 165 ribosomal RNA. Plant Physiol 164:201-215

Han B, Xu S, Xie YJ, Huang JJ, Wang LJ, Yang Z, Zhang CH, Sun Y, Shen WB, Xie GS (2012) ZmHO-1, a maize haem oxygenase-1 gene, plays a role in determining lateral root development. Plant Sci 184:63-74

Hoagland DR, Arnon DI (1950) The water-culture method for growing plants without soil. Calif Agr Expt Sta 347:1-32

Kreps JA, Wu Y, Chang HS, Zhu T, Wang X, Harper JF (2002) Transcriptome changes for Arabidopsis in response to salt, osmotic, and cold stress. Plant Physiol 130:2129-2141

Kumutha D, Ezhilmathi K, Sairam RK, Srivastava GC, Deshmukh PS, Meena RC (2009) Waterlogging induced oxidative stress and antioxidant activity in pigeonpea genotypes. Biol Plant 53:75-84

Li HY, Chang CS, Lu LS, Liu CA, Chan MT, Charng YY (2003) Over-expression of Arabidopsis thaliana heat shock factor gene (AtHsfA1b) enhances chilling tolerance in transgenic tomato. Bot Bull Acad Sinica 44:129-140

Limm EB, Simonin KA, Bothman AG, Dawson TE (2009) Foliar water uptake: a common water acquisition strategy for plants of the redwood forest. Oecologia 161:449-459

Liu MS, Li HC, Chang YM, Wu MT, Chen LF (2011) Proteomic analysis of stress-related proteins in transgenic broccoli harboring a gene for cytokinin production during postharvest senescence. Plant Sci 181:288-299

Liu MS, Li HC, Lai YM, Lo HF, Chen LF (2013) Proteomics and transcriptomics of broccoli subjected to exogenously supplied and transgenic senescenceinduced cytokinin for amelioration of postharvest yellowing. J proteomics 20:133-144

Markus V, Lurie S, Bravdo B, Stevens MA, Rudich J (1981) High temperature effects on RuBP earboxylase and carbonic anhydrase activity in two tomato cultivars. Physiol Plant 53:407-412

Miller SR, McGuirl MA, Carvey D (2013) The evolution of RuBisCO stability at the thermal limit of photoautotrophy. Mol Biol Evol 30:752-760

Mittler R (2006) Abiotic stress, the field environment and stress combination. Trends Plant Sci 11:15-19

Mittler R, Vanderauwera S, Gollery M, Van Breusegem F (2004) Reactive oxygen gene network of plants. Trends Plant Sci 9:490-498

Mittler R, Vanderauwera S, Suzuki N, Miller G, Tognetti VB, Vandepoele K, Gollery M, Shulaev V, Van Breusegem F (2011) ROS signaling: the new wave? Trends Plant Sci 16:300-309
Moller IM, Kristensen BK (2004) Protein oxidation in plant mitochondria as a stress indicator. Photochemical and photobiological sciences. Photoch Photobio Sci 3:730-735

Ohara N, Naito M, Miyazaki C, Matsumoto S, Tabira Y, Yamada T (1997) HrpA, a new ribosome-associated protein which appears in heat-stressed Mycobacterium bovis bacillus Calmette-Guerin. J Bacteriol 179:6495-6498

Pucciariello C, Banti V, Perata P (2012) ROS signaling as common element in low oxygen and heat stresses. Plant Physiol Biochem 59:3-10

Rizhsky L, Liang H, Shuman J, Shulaev V, Davletova S, Mittler R (2004) When defense pathways collide. The response of Arabidopsis to a combination of drought and heat stress. Plant Physiol 134:1683-1696

Salvucci ME (2008) Association of Rubisco activase with chaperonin-60b: a possible mechanism for protecting photosynthesis during heat stress. J Exp Bot 59:1923-1933

Seki M, Narusaka M, Ishida J, Nanjo T, Fujita M, Oono Y, Kamiya A, Nakajima M, Enju A, Sakurai T, Satou M, Akiyama K, Taji T, Yamaguchi-Shinozaki K, Carninci P, Kawai J, Hayashizaki Y, Shinozaki K (2002) Monitoring the expression profiles of 7000 Arabidopsis genes under drought, cold and high-salinity stresses using a full-length cDNA microarray. Plant J 31:279-292

Simova-Stoilova L, Demirevska K, Kingston-Smith A, Feller U (2012) Involvement of the leaf antioxidant system in the response to soil flooding in two Trifolium genotypes differing in their tolerance to waterlogging. Plant Sci 183:43-49

Tabira Y, Ohara N, Yamada T (2000) Identification and characterization of the ribosome-associated protein, HrpA, of Bacillus Calmette-Guerin. Microb Pathogen 29:213-222

Uchida A, Jagendorf AT, Hibino T, Takabe T, Takabe T (2002) Effects of hydrogen peroxide and nitric oxide on both salt and heat stress tolerance in rice. Plant Sci 163:515-523

Wang G, Kong F, Zhang S, Meng X, Wang Y, Meng Q (2015) A tomato chloroplast-targeted DnaJ protein protects Rubisco activity under heat stress. J Exp Bot. doi:10.1093/jxb/erv102

Wei MY, Chao YY, Kao C (2012) NaCl-induced heme oxygenase in roots of rice seedlings is mediated through hydrogen peroxide. Plant Growth Regul 69:1-6

Xu Q, Xu X, Shi Y, Xu J, Huang B (2014) Transgenic tobacco plants overexpressing a grass ppexp 1 gene exhibit enhanced tolerance to heat stress. PLoS ONE 9:e100792

\section{Submit your manuscript to a SpringerOpen ${ }^{\odot}$ journal and benefit from:}

- Convenient online submission

$\checkmark$ Rigorous peer review

- Immediate publication on acceptance

- Open access: articles freely available online

- High visibility within the field

- Retaining the copyright to your article

Submit your next manuscript at $>$ springeropen.com 